\title{
Gonadotropin treatment augments postnatal oogenesis and primordial follicle assembly in adult mouse ovaries?
}

Deepa Bhartiya ${ }^{*}$, Kalpana Sriraman, Pranesh Gunjal and Harshada Modak

\begin{abstract}
Background: Follicle stimulating hormone (FSH) exerts action on both germline and somatic compartment in both ovary and testis although FSH receptors (FSHR) are localized only on the somatic cells namely granulosa cells of growing follicles and Sertoli cells in the seminiferous tubules. High levels of FSH in females are associated with poor ovarian reserve, ovarian hyper stimulation syndrome etc. and at the same time FSH acts as a survival factor during in vitro organotypic culture of ovarian cortical strips. Thus a further understanding of FSH action on the ovary is essential. We have earlier reported presence of pluripotent very small embryonic-like stem cells (VSELs express Oct-4A in addition to other pluripotent markers) and their immediate descendants 'progenitors' ovarian germ stem cells (OGSCs express Oct-4B in addition to other germ cell markers) in ovarian surface epithelium (OSE) in various mammalian species including mice, rabbit, monkey, sheep and human. Present study was undertaken to investigate the effect of pregnant mare serum gonadotropin (PMSG) on adult mice ovaries with a focus on VSELS, OGSCs, postnatal oogenesis and primordial follicle assembly.

Methods: Ovaries were collected from adult mice during different stages of estrus cycle and after 2 and 7 days of PMSG (5 IU) treatment to study histo-architecture and expression for FSHR, pluripotent stem cells, meiosis and germ cell specific markers.

Results: PMSG treatment resulted in increased FSHR and proliferation as indicated by increased FSHR and PCNA immunostaining in OSE and oocytes of primordial follicles (PF) besides the granulosa cells of large antral follicles. Small 1-2 regions of multilayered OSE invariably associated with a cohort of PF during estrus stage in control ovary were increased to 5-8 regions after PMSG treatment. This was associated with an increase in pluripotent transcripts (Oct-4A, Nanog), meiosis (Scp-3) and germ cells (Oct-4B, Mvh) specific markers. MVH showed positive immuno staining on germ cell nest-like clusters and at places primordial follicles appeared connected through oocytes.

Conclusions: The results of the present study show that gonadotropin (PMSG) treatment to adult mouse leads to increased pluripotent stem cell activity in the ovaries, associated with increased meiosis, appearance of several cohorts of PF and their assembly in close proximity of OSE. This was found associated with the presence of germ cell nests and cytoplasmic continuity of oocytes in PF. We have earlier reported that pluripotent ovarian stem cells in the adult mammalian ovary are the VSELS which give rise to slightly differentiated OGSCs. Thus we propose that gonadotropin through its action on pluripotent VSELs augments neo-oogenesis and PF assembly in adult mouse ovaries.
\end{abstract}

Keywords: Ovary, PMSG, Stem cells, VSELs, Primordial follicles, Oct-4

\footnotetext{
* Correspondence: deepa.bhartiya@yahoo.in

Stem Cell Biology Department, National Institute for Research in

Reproductive Health, Mumbai 400 012, India
} 


\section{Background}

Follicle-stimulating hormone (FSH) is a pleiotropic hormone produced by the pituitary and exerts its action on the ovary by inducing proliferation, differentiation and steroidogenesis in the granulosa cells of growing preovulatory follicles. The initial development of primordial follicles (PF) is believed to be FSH independent [1]. However, several reports have shown that appreciable amount of FSH is present in serum of perinatal mice [2], rats [3], hamsters [4,5] and humans [6]. Elevated FSH levels are found to be associated with altered ovarian function including diminished ovarian reserve, pre-mature ovarian failure, infertility, ovarian hyper-stimulation syndrome, poor quality of eggs, menopause $[7,8]$ and also a huge body of literature exists suggesting an association with ovarian cancers $[9,10]$. At the same time, FSH acts as a survival factor during PF transition to primary/ secondary follicles in serum-free ovarian cortical tissue culture [11]. Studies in hamster using anti-FSH antibodies have shown that FSH action is also required for formation of primordial follicles [12]. They showed that a single dose of FSH specific polyclonal antibody during gestational period could significantly affect the number of primordial follicles after birth. Demeestere et al. [13] recently concluded that FSH possibly coordinates development of both germline and somatic compartments of the mouse follicle. FSH is also known to exert similar dual effect on both the germline and somatic cells in the testis. Rao et al. [14] reported that by blocking the action of FSH using phage-expressed extracellular domain of FSHR results in azoospermia after 100 days in non-human primates although FSHR are localized only on the surface of Sertoli cells. It remains rather unclear as to how FSH can exert action on both somatic and germline compartment of the ovarian follicles and in the testis, although FSHR are expressed only on the somatic cells namely granulosa cells of developing follicles and on Sertoli cells in the testis. Although indirect action on germ cells through paracrine-autocrine interactions is suggested, mechanism underlying FSH action on the mammalian gonads needs further investigation.

Several published reports using ovarian tissue or immortalized ovarian epithelial cell lines show that besides granulosa cells, FSH receptors (FSHR) are also localized on the normal ovary surface epithelium [15-17] and in ovarian tumor surface epithelium [9,18-26]. Oocytes have also been reported to express FSHR. FSHR mRNA was detected in the oocytes and cleavage stage mouse embryos [27]. FSHR is reported to be 20 fold higher in the human oocytes compared to granulosa cells [28]. Various techniques like in situ hybridization, RT-PCR, Q- PCR and immunolocalization studies have been used to demonstrate FSHR in the OSE of mice, rats, cows and humans $[9,15,17,19]$. Few studies have also shown that OSE undergoes rapid proliferation in response to PMSG [29-31], based on BrdU uptake or PCNA staining. All these studies suggest that FSH acting through FSHR localized in OSE may have an important role in ovarian biology. It is imperative to mention here that these published reports assume greater significance, since recently it has been reported by several groups [32-38] that the OSE also houses ovarian stem cells which may contribute to postnatal oogenesis. Hence, PMSG induced FSH action in adult mouse can serve as a good model to understand the probable mechanism of FSH action on stem cells as well as in new follicular development. Our group earlier reported that OSE in mice, rabbits, sheep, monkeys and women harbors two distinct stem cell populations that include the pluripotent very small embryoniclike stem cells (VSELs) and their immediate descendants 'progenitors' ovarian germ stem cells (OGSCs) [32,39]. We have further implicated these stem cells in postnatal oogenesis and proposed a working model for the same [39].

The concept of postnatal oogenesis in mammalian ovary is a highly debated area of research and several investigators have contributed both in favor [36,39-42] and against $[43,44]$ in the recent past. Tilly's and coworkers [36] were the initial group to generate evidence against the concept of fixed number of eggs at the time of birth and their recent paper [45] provides unequivocal evidence to support the presence of mitotically active germ cells that can generate oocytes both in vitro and in vivo. The existing controversy regarding existence of stem cells in adult mammalian ovary appears to be more of technical nature [46] or markers [47] used to study the stem cells rather than absence of stem cells itself. Recently, Gamwell and co-workers [48] recently reported a side population in mouse OSE that excludes Hoechst dye and express Sca-1 along with Nanog and Kit.

The present study was undertaken to study the effect of PMSG on mouse ovary with a focus on stem cells located in the OSE. Besides normal estrus cycle, ovaries were studied 2 and 7 days after PMSG treatment. Normally 2 days are required to stimulate maturation of follicles in a standard super-ovulation protocol using PMSG and hence 2 days was chosen to study the standard effect. A longer time period of 7 days was chosen to understand delayed effect and to get insights into the effect of FSH on ovarian stem cells. What is the effect of FSH when the ovary is super-ovulated during assisted reproduction, how does FSH treatment affect the OSE, does it have any effect on the stem cells and whether postnatal oogenesis and PF assembly is affected by FSH treatment are open questions that remain to be answered.

\section{Materials \& methods}

The study was approved by Institute Animal Ethics Committee and was carried out using in-house bred 
Table 1 Experimental design of the study

\begin{tabular}{lllll}
\hline Stage & $\begin{array}{l}\text { Total number } \\
\text { of animals }\end{array}$ & Total & $\begin{array}{l}\text { Histology } \\
\text { and IHC }\end{array}$ & $\begin{array}{l}\text { RNA } \\
\text { isolation }\end{array}$ \\
\cline { 3 - 5 } & 2 & 4 & 4 & - \\
\hline Estrous & 2 & 2 & 2 & - \\
Pro-estrus & 1 & 20 & 8 & 12 \\
Di-estrus & $10^{*}$ & 24 & 14 & 10 \\
2D PMSG & $12^{*}$ & 24 & 14 & 10 \\
7D PMSG & $12^{*}$ & 24 & \\
\hline
\end{tabular}

* Total number of animals used in 4 different experiments.

${ }^{\S}$ Whole ovary was sectioned and every third slide was used for H\&E staining The rest of the slides were used for IHC.

\#Two ovaries from two animals were pooled to make one sample for RNA isolation. Only samples showing good $A_{260} / A_{280}$ ratio after RNA isolation were used for RT/Q-PCR study.

Swiss mice in the experimental animal facility at our Institute. Mice were housed in a temperature and humidity controlled room on a $12 \mathrm{hr}$ light/12hr darkness cycle with free access to food and water.

Different stages of estrus cycle were monitored by daily examination of vaginal smears of one month old female mice. Briefly, the vaginal swabs were prepared using sterile PBS dipped cotton swabs, fixed in 100\% methanol, stained with Giemsa and observed under a 90i microscope (Nikon, Tokyo, Japan). Ovaries were collected during different stages of estrus cycle namely estrus, proestrus and diestrus (DE). Ovaries were also collected from mice treated with subcutaneous injection of 5IU PMSG (National Hormone \& Peptide Program, Harbor-UCLA Medical Center, California, USA) after 2 days (2D) and 7 days (7D) of treatment. All PMSG injections were done in normal cycling mice at $\mathrm{DE}$ stage and mice at DE stage were used as controls for the experiments. The experimental design and number of animals used in the present study are shown in Table 1 . The collected ovaries were fixed in $4 \%$ formalin for histology and immunolocalization studies and also in TRIZOL for RNA extraction to analyze various gene transcripts of interest by RT-PCR and Q-PCR. The ovaries were carefully dissected from all the adhering extraneous tissue under a stereomicroscope with the help of a micro scissor prior to freezing for RNA.

\section{Histological studies}

Formalin fixed ovaries were processed and embedded in paraffin using standard protocols. $5 \mu \mathrm{m}$ thick sections of the embedded ovaries were prepared and stained with Hematoxylin and Eosin for studying the histo- architecture during different phases of estrus cycle and after treatment with PMSG. The representative areas were photographed using 90i microscope and data recorded.

\section{Immunohistochemistry (IHC)}

Immunolocalization studies were carried out for various antigens listed in Table 2. Briefly, the paraffin sections were deparaffinized, hydrated and antigen retrieval was performed with boiling SSC buffer of pH 6 in microwave for $5 \mathrm{~min}$ (cytoplasmic antigens) or $15 \mathrm{~min}$ (nuclear antigens). After cooling, the slides were washed with Tris buffer saline (TBS) for 5 min and processed further for blocking with $10 \%$ NGS and $1 \%$ BSA in TBS. After removing excess blocking reagent, the slides were incubated with primary antibody diluted with $1 \%$ BSA in TBS for two hrs at room temperature. For negative control, the antibody was omitted and sections were incubated with $1 \%$ BSA in TBS. In case of FSHR detection alone, negative control included the pre-immune sera from rabbit in which the primary antibody was raised. The detection was done using anti mouse Vecta $A B C$ kit (Vector Laboratories, USA) according to manufacturer's instructions. Final color development was done using DAB (Biogenex, USA). After counterstaining with Haematoxylin, the slides were observed under $90 \mathrm{i}$ microscope. Representative areas were photographed.

\section{RNA isolation and CDNA synthesis}

Total RNA was extracted by standard protocol using Trizol (Invitrogen, Carlsbad- CA, USA) and treated with DNase I (Amersham Biosciences, Piscataway, NJ) to remove any genomic DNA present. First-strand cDNA was synthesized using the iScript cDNA synthesis kit (Bio-Rad, USA) according to the manufacturer's instructions. Briefly, $1 \mu \mathrm{g}$ of total RNA was incubated with $5 \mathrm{x}$ reaction mix and reverse transcriptase mix. The reaction was carried out in G-STORM thermocycler (Gene

Table 2 Details of antibodies used for immunolocalization studies

\begin{tabular}{|c|c|c|c|c|c|}
\hline Antibody & Marker & Source & Dilution & Reason to conduct IHC & Ref \\
\hline FSHR Polyclonal & FSHR: membrane bound receptor of FSH & Gift & $1: 100$ & To study cells responsive to PMSG & [49] \\
\hline $\begin{array}{l}\text { PCNA } \\
\text { Monoclonal }\end{array}$ & $\begin{array}{l}\text { PCNA: nuclear protein that functions during } \\
\text { DNA replication }\end{array}$ & Sigma & $1: 5000$ & To study proliferating cells & {$[50]$} \\
\hline OCT-4 Polyclonal & $\begin{array}{l}\text { OCT-4 isoforms: OCT- } 4 \mathrm{~A} \text { is a nuclear transcription } \\
\text { factor and OCT- } 4 \mathrm{~B} \text { is cytoplasmic }\end{array}$ & Abcam & $1: 100$ & $\begin{array}{l}\text { To study pluripotent and progenitor } \\
\text { stem cells }\end{array}$ & [32] \\
\hline SCP3 Polyclonal & $\begin{array}{l}\text { SCP3: a nuclear protein required for homologous } \\
\text { recombination during meiosis I }\end{array}$ & Abcam & $1: 500$ & $\begin{array}{l}\text { To study presence of cells undergoing } \\
\text { meiosis }\end{array}$ & [36] \\
\hline VASA Polyclonal & $\begin{array}{l}\text { MVH: germ cell specific cytoplasmic protein } \\
\text { expressed from primordial germ cell stage }\end{array}$ & $\begin{array}{l}\text { R\&D } \\
\text { System }\end{array}$ & $1: 500$ & To study early germ cells and oocytes & {$[51,52]$} \\
\hline
\end{tabular}


Technologies, Braintree, UK). The reaction mix was first incubated at $25^{\circ} \mathrm{C}$ for $5 \mathrm{~min}$, then at $42^{\circ} \mathrm{C}$ for $30 \mathrm{~min}$ and finally at $85^{\circ} \mathrm{C}$ for $5 \mathrm{~min}$.

Both RT-PCR and Q-PCR were employed to study gene transcripts expression for the following markers: pluripotent stem cell specific markers (Oct-4A: isoform A of octamer binding transcription factor 4 [53,54] and Nanog: homeobox transcription factor also expressed in primordial germ cells [55]); early primordial germ cell markers (Oct-4, represented here as total Oct-4 as it includes all isoforms of Oct-4 including isoform B expressed in cytoplasm of OGSCs [32]), Stella [56], Fragilis [57], Mvh mouse vasa homolog, plays a role in oogenesis, germ cell and follicle development); $\underline{\text { oocyte }}$ specific markers (Nobox newborn ovary homeoboxencoding gene is essential for folliculogenesis [58], HoxA10 homoeobox gene restricted to primordial and early primary follicular oocytes [58]); pre-meiotic marker (Stra8 stimulated by retinoic acid gene 8 essential for meiotic initiation [59]); meiotic marker (Scp3 synaptonemal complex protein 3 and Dmc1 required for, meiosis specific homologous recombination) and PMSG action mediator (Fshr). Each sample was obtained by pooling ovaries from two different animals.

\section{Reverse -transcription PCR}

RT-PCR was carried out to study the expression of meiotic markers (Stra 8, Scp3 and Dmc1) using Dream Taq DNA polymerase (Fermentas Life Sciences; Vilnius, Lithuania). Briefly, the cDNA mix $(2 \mu \mathrm{l})$ was amplified using $0.2 \mathrm{mM}$ of each primer (Table 3), 1.25 unit of DreamTaq DNA polymerase (Fermentas) in $1 \mathrm{x}$ Dream Taq buffer (Fermentas) and 0.2mM dNTPs in a G-STORM thermocycler. Amplification was carried out for 35 cycles, with each cycle consisting of denaturation at $94^{\circ} \mathrm{C}$ for $30 \mathrm{sec}$, annealing at the specified temperature (Table 3) for $20 \mathrm{sec}$, and extension at $72^{\circ} \mathrm{C}$ for $30 \mathrm{sec}$. The products were analyzed on $2 \%$ agarose gel stained with $0.5 \mu \mathrm{g} / \mathrm{ml}$ ethidium bromide (Bangalore Genei, Bangalore, India). The product size was approximated using a 100-bp DNA ladder (Bangalore Genei). The negative control did not include cDNA in the reaction mixture. Normal adult mouse testis was used as positive control.

\section{Quantitative PCR}

Q-PCR was carried out to study the expression of various gene transcripts mentioned in Table 3. The expression levels of these gene transcripts in relation to housekeeping gene transcript $18 \mathrm{~s}$ were estimated by CFX96 Real-time PCR system (Bio-Rad Laboratories, Hercules, CA) using SYBR Green chemistry (Bio-Rad).

The primers and their respective annealing temperatures used in the study are mentioned in Table 3. All the primers
Table 3 Primers used for RT- PCR and Q-PCR

\begin{tabular}{|c|c|c|}
\hline Gene & Primer & $\begin{array}{l}\text { Annealing } \\
\text { Temp }\left({ }^{\circ} \mathrm{C}\right) \\
\end{array}$ \\
\hline \multirow[t]{2}{*}{ Fshr } & F: TGGAGGCGGCAAACCTCTGAAC & 65 \\
\hline & R: TCTGGCTTTGGCGAGCAGGTC & \\
\hline \multirow[t]{2}{*}{ Oct-4A } & F: CCATGTCCGCCCGCATACGA & 61 \\
\hline & R: GGGCTITCATGTCCTGGGACTCCT & \\
\hline Total & F: CCTGGGCGTTCTCTTTGGAAAGGTG & 68 \\
\hline Oct-4 & R: GCCTGCACCAGGGTCTCCGA & \\
\hline \multirow[t]{2}{*}{ Nanog [34] } & F: CAGGAGTTTGAGGGTAGCTC & 61 \\
\hline & R: CGGTTCATCATGGTACAGTC & \\
\hline \multirow[t]{2}{*}{ Stella } & F: ACGCTTTGGATGATACAGACGTCC & 67 \\
\hline & R: GCGCTTTGAACTTCCCTCCGGA & \\
\hline \multirow[t]{2}{*}{ Fragilis } & F: GGGGTGACTGAGCTGGGGGAA & 65 \\
\hline & R: TGTCCCTAGACTTCACAGAGTAGGC & \\
\hline \multirow[t]{2}{*}{ Nobox } & F: AGGGTGCTGAGAGGGTGGCAG & 66 \\
\hline & R: GGCGATACTAGTGCCCCAGGAC & \\
\hline \multirow[t]{2}{*}{ HoxA10 } & F:CACTTGTCCGGCACCCCTTCG & 65 \\
\hline & R: TTCGCCTITGGAACTGCCTTGAC & \\
\hline \multirow[t]{2}{*}{ Mvh } & F: AGTGGAAGTGGTCGAGGTGGT & 61 \\
\hline & R: TGCCGGTGGTGCATCATGTCC & \\
\hline \multirow[t]{2}{*}{ Scp3 } & F: TGTTGCAGCAGTGGGAACTGGAT & 68 \\
\hline & R: CCATCTCTTGCTGCTGAGTTTCCA & \\
\hline \multirow[t]{2}{*}{ Dmc-1 } & F: TGGGGAATTGGCTGAACGCC & 68 \\
\hline & R: CAGGCATCTCGGGGCTGTCATAA & \\
\hline \multirow[t]{2}{*}{ Stra8 } & F: GTTCCTGCGTGTTCCACAAG & 61 \\
\hline & R: CACCCGAGGCTCAAGCTTC & \\
\hline \multirow[t]{2}{*}{$18 \mathrm{~s}$} & F:GGAGAGGGAGCCTGAGAAAC & 61 \\
\hline & R: CCTCCAATGGATCCTCGTTA & \\
\hline \multirow[t]{2}{*}{ Gapdh [34] } & F: GTCCCGTAGACAAAATGGTGA & 58 \\
\hline & R: TGCATTGCTGACAATCTTGAG & \\
\hline
\end{tabular}

had efficiency close to $100 \%$ and all primers except Gapdh and Nanog are exon-exon spanning primers. The amplification conditions included initial denaturation at $94^{\circ} \mathrm{C}$ for 3 min followed by 40 cycles comprising of denaturation at $94^{\circ} \mathrm{C}$ for 30 secs, primer annealing for 20 secs and extension at $72^{\circ} \mathrm{C}$ for 30 secs. The final step included incubation at $94^{\circ} \mathrm{C}$ for 20 secs to remove any secondary structures followed by melt curve analysis. The fluorescence emitted at each cycle was collected during the extension step of each cycle. The homogeneity of the PCR amplicons was verified by running the products on $2 \%$ agarose gels and also by studying the melt curve. All PCR amplifications were carried out in duplicate. Mean $\mathrm{Ct}$ values generated in each experiment using the CFX Manager software (Bio-Rad) were used to calculate the mRNA expression levels. Since $\Delta \mathrm{Ct}$ is inversely proportional to relative mRNA expression levels, the levels were calculated manually by the $\Delta \mathrm{Ct}$ method. 


\section{Results}

\section{Histological studies}

Ovarian surface epithelium (OSE) during different stages of estrus cycle

Majority of epithelium covering the ovarian surface during different stages of the estrus cycle comprised of cuboidal or flat epithelial cells (Figure 1 \& 2). In comparison to diestrus stage (Figure 1 A \& B) where OSE was cuboidal to flat, small regions of OSE appeared prominent and highly folded, gave multilayered appearance in proestrus and estrus stages (Figure $1 \mathrm{C} \& \mathrm{D}$, Figure 2 respectively). Cohorts of PFs were invariably visualized under this region of OSE, especially during the estrus stage. At places, relatively large cells with pale cytoplasm, surrounded by a single layer of somatic granulosa-like cells were observed in the OSE (Figure 2 C-F). The cohorts of PFs appeared to have cytoplasmic continuity at places (Figure $2 \mathrm{D} \& \mathrm{~F}$ ). It appeared as if PF undergo follicular assembly in the OSE and then get pinched off from the OSE and shift to the cortex region just below the OSE always in a cohort.

\section{Ovarian surface epithelium after two (2D) and seven (7D) days post PMSG treatment}

PMSG had a profound effect on OSE in addition to its known effect on growing cohort of follicles. 2D after PMSG treatment, OSE exhibited extensive proliferation in agreement with earlier reports [29-31]. We also observed OSE having multilayered appearance along with the presence of small outgrowths, which enclosed many PFs (Figure 3). Increased vascularity near the OSE was also observed. The ovaries from 7D PMSG treated mice showed striking difference when compared at lower magnification to ovary from control (Figure $4 \& 5$ ). As evident, in control ovarian section during the estrus phase, only a single small region of OSE showed proliferation, had multilayer appearance and a cohort of PF was observed (Figure 4A). In contrast, the OSE after 7D of PMSG revealed the presence of 5-8 regions where the OSE was of hyper proliferative nature accompanied with the presence of several cohorts of PF (Figure 4B, Figure 5A \& B). However, in comparison to 2D, the protuberances in OSE were reduced on 7D. At places, PF assembly was evident in OSE (Figure 5 \& 6) wherein a large germ cell with abundant pale cytoplasm was observed in the OSE. Nests of follicles were also observed with prominent ooplasm continuity. It appeared that after PF assembly, these PF were pinched off and shifted to the ovarian cortex just below the OSE, similar to control ovaries in the estrus phase (Figure 2). However, PMSG exposure accelerated the frequency of the whole process of oogenesis and PF assembly.

\section{Immunolocalization studies}

\section{FSH receptors}

FSHR immunolocalization was relatively less in control ovarian sections (Figure 7A \& B). Minimal staining was observed in OSE, oocytes and corpus luteal cells whereas
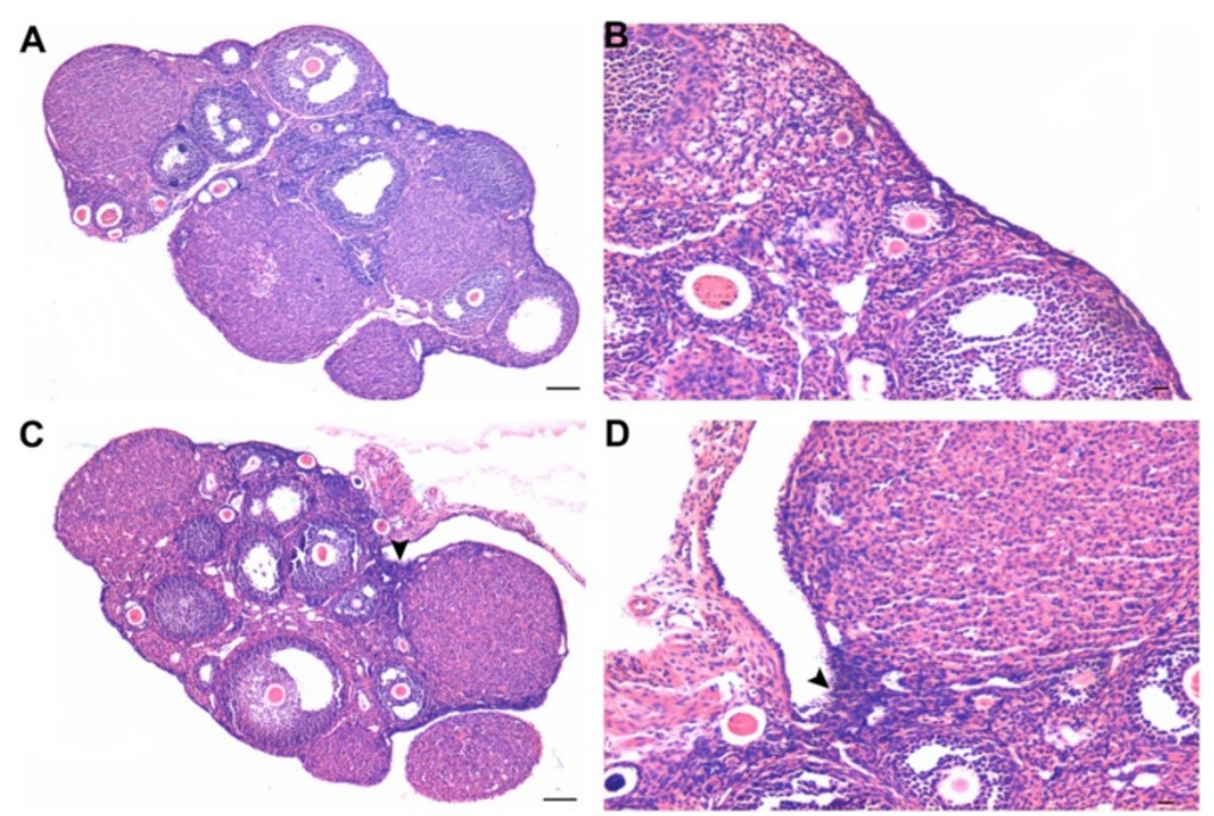

Figure 1 Whole ovary histo-architecture during different stages of estrus cycle in one month old Swiss mice. Follicles in different stages of development and corpus lutea can be observed. A \& B During di-estrus stage, the ovarian surface is covered with cuboidal or flat epithelial cells. C \& D During pro-estrus stage, a small area of the surface epithelial crypt reveals the presence of columnar epithelial cells (arrowhead).





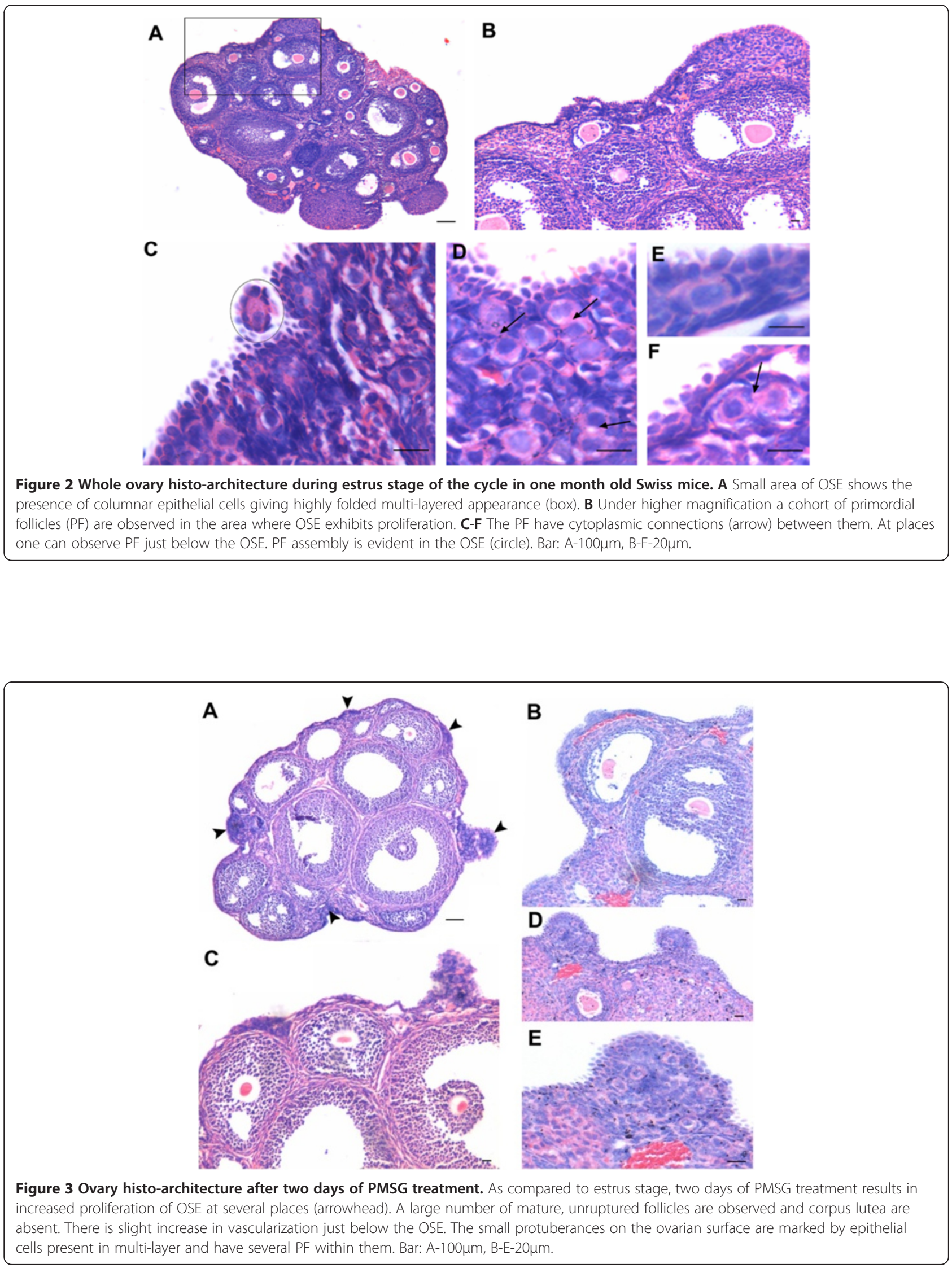

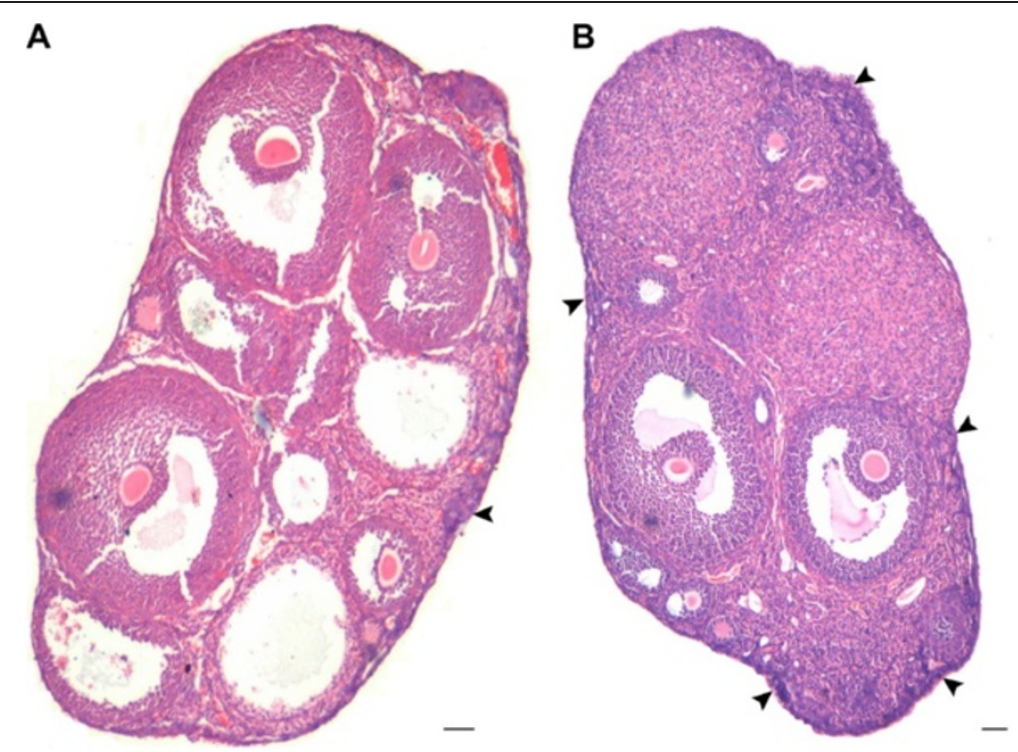

Figure 4 A comparative histo-architecture of mouse ovary during normal estrus stage and 7 days after PMSG treatment. As evident, focal areas where OSE gives multilayer appearance and has associated cohort of PF are markedly increased after PMSG treatment $\mathbf{B}$ (arrow head) as compared to control A Bar: $100 \mu \mathrm{m}$.

dark and prominent staining was observed in the granulosa cells of mature follicles (Figure 7B). The oocyte also showed positive immunostaining for FSHR (Figure 7A \& B). PMSG treatment had a profound effect on FSHR expression pattern in the ovarian sections (Figure 7C-D). An increased staining was observed in granulosa cells, OSE cells (Figure 6C) and oocytes of primordial, primary and secondary follicles. The granulosa cells in primordial follicle were distinctly negative for FSHR.

\section{PCNA}

As compared to control (Figure 8A), PMSG treated OSE (Figure 8B \& C) showed increased PCNA staining. The

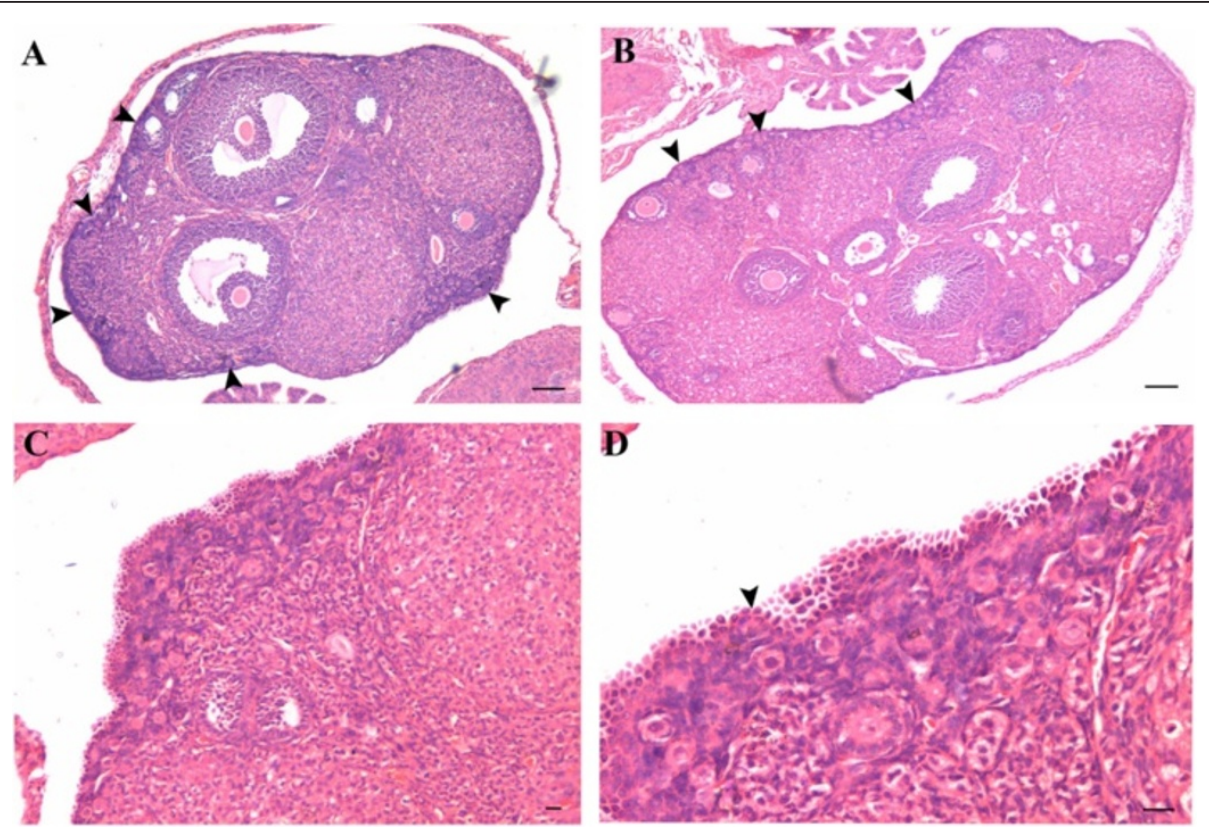

Figure 5 Ovarian histo-architecture after $\mathbf{7}$ days of PMSG treatment. A \& B Whole ovary sections showing several focal areas with multilayered OSE and associated cohorts of PF. C \& D Higher magnification of the region with multilayer OSE and PF. PF assembly in the OSE is

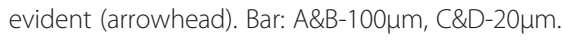



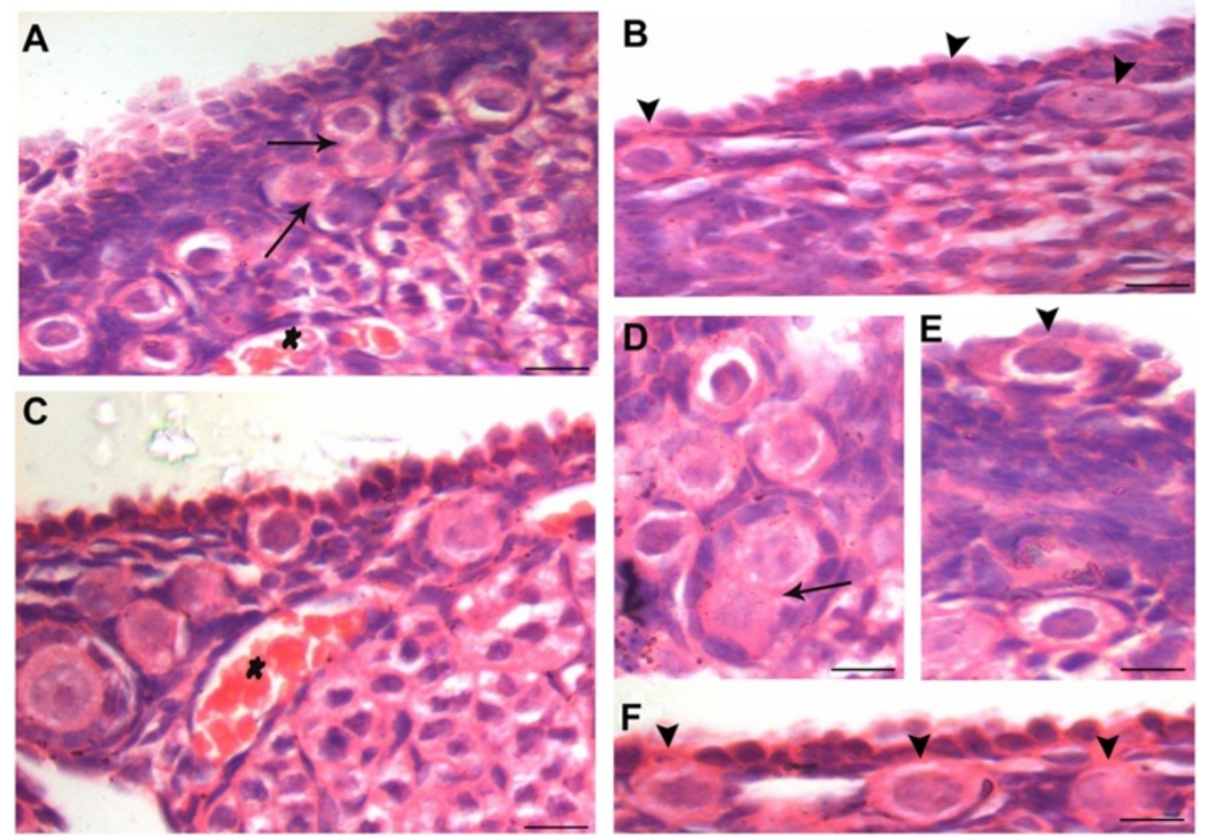

Figure 6 Higher magnification of D7 PMSG treated H \& E stained ovarian sections. The epithelial cells appear proliferative and multilayered. A cohort of PF is invariably observed below such regions of OSE. Note increased vascularity in this region (star) and cytoplasmic connection between the oocytes of two adjacent PF (arrows). The PF assembly occurs in the OSE (arrowhead). The oocytes are large in size with abundant

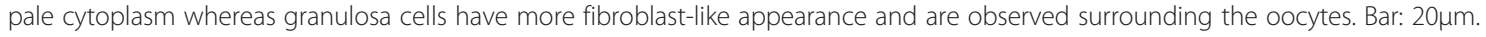
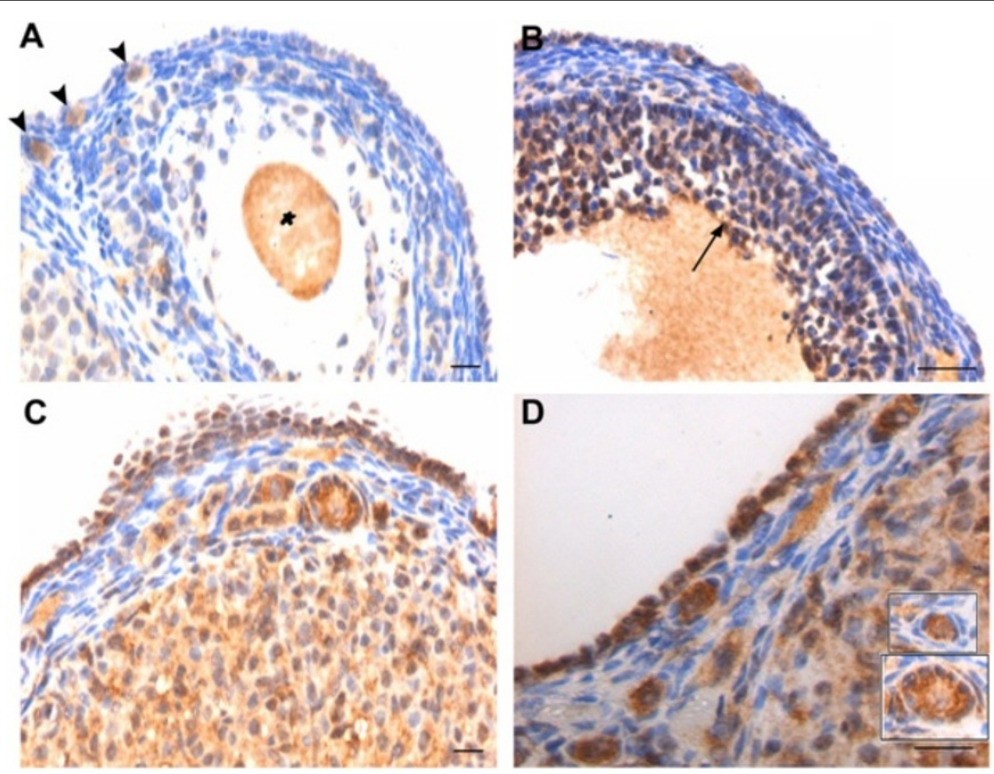

Figure 7 Follicle stimulating hormone receptor (FSHR) immunolocalization in estrus stage and after 7D of PMSG treatment. A \& B In control, minimal staining is observed in the OSE cells. However, distinct immunolocalization is observed in the oocyte of the PF (black arrow), whereas the surrounding granulosa cells are negative. The granulosa cells in large follicles show positive staining (blue arrow). Positive staining is also observed in the oocyte in large follicle (asterisk). C \& D Increased immunostaining pattern is observed after PMSG treatment in the multilayered OSE, oocytes of primordial and developing primary to secondary follicles. Inserts show follicles in various developmental stages with granulosa cells negative for FSHR. Note change in shape of the granulosa cells from flat to cuboidal as the PF transits into a primary follicle.

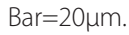


germ cell nuclei of PFs in the OSE also showed prominent staining suggesting the PFs were newly assembled (Figure 8B'). PCNA labeling was also observed in the granulosa cells of developing follicles. As expected, the oocytes of bigger follicles were negative for PCNA (data not shown).

\section{OCT-4}

In control samples, faint OCT-4 staining was observed in the ooplasm of primordial follicles (Figure 8D). In 7D PMSG treated ovarian sections, OCT-4 staining was more intense and the PFs lying below the OSE showed both nuclear (arrowhead) and cytoplasmic staining for OCT-4. However, the surrounding granulosa cells were distinctly negative for OCT-4 (Figure $8 \mathrm{E} \mathrm{\&} \mathrm{F)} \mathrm{in} \mathrm{both}$ control and after PMSG treatment.

\section{MVH}

MVH (a proliferating germ cell and oocyte marker) was localized in the ooplasm of primordial to secondary follicular oocytes (Figure 8G). Some of the primordial follicles in cohorts still appeared cytoplasmically connected without any intervening granulosa cell (Figure 8G', arrowhead) and exhibited positive MVH staining. Also at places cluster of germ cells in the OSE also stained positive for MVH (Figure 8G, arrow), probably representing mitotically dividing pre-meiotic germ cell nests, which are well documented in perinatal mouse ovary [60].

\section{$S C P 3$}

SCP3, a meiotic marker was distinctly immuno-localized in the nuclei of some oocytes along OSE after PMSG treatment. The staining of SCP3 was evenly localized throughout the nuclei in 7D post PMSG (Figure $8 \mathrm{H}-\mathrm{J}$ ) suggesting oocytes in meiosis prophase I. Nucleolar staining was occasionally observed in primordial follicles of control as well as in 2D post treatment (data not shown).

\section{Gene transcript analysis \\ $R T-P C R$}

Figure 9 shows RT-PCR results for pre-meiotic and meiotic markers using normal adult testicular tissue as positive control. Only few of the samples namely control C2, 2D2 and 7D1 of PMSG treated samples showed faint positivity for Stra8 when compared to brightly positive band from control testicular samples. This may be because very few cells in whole ovary undergo meiosis and normally STRA8 positive cells are rarely detected in young adults [61]. Niikura et al. [61] suggested that this

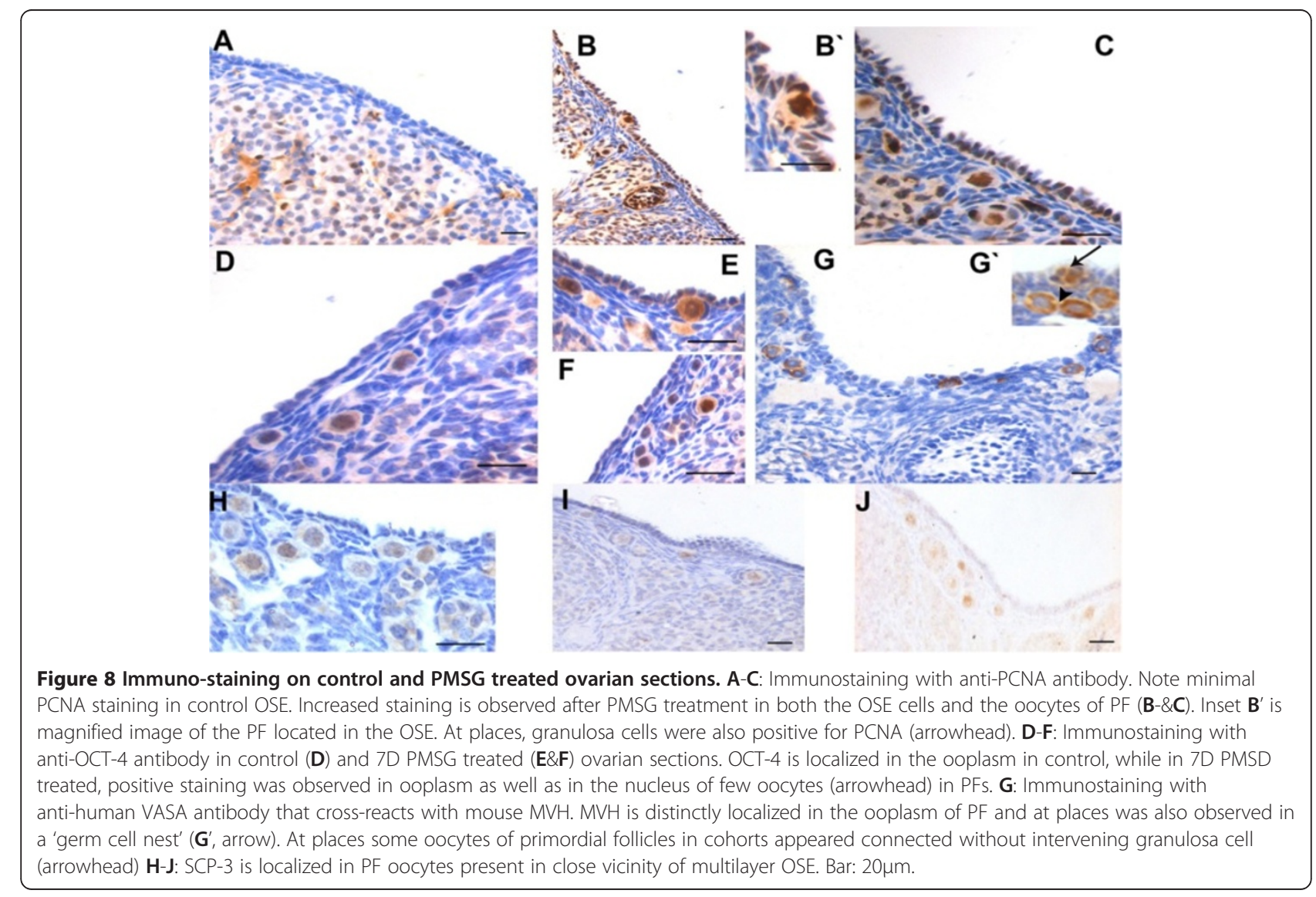




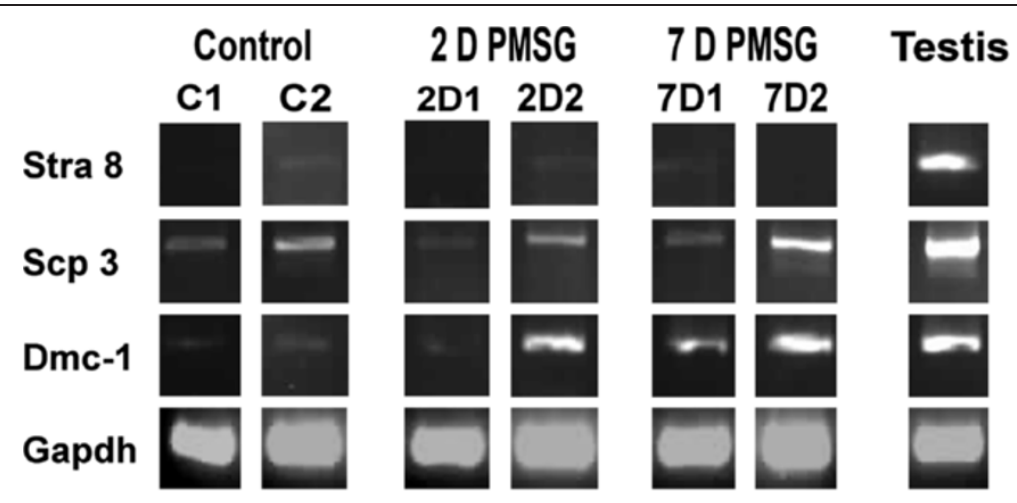

Figure 9 RT-PCR results for pre-meiotic (Stra8) and meiotic (Scp3, Dmc-1) markers in control and PMSG treated ovaries along with testis as positive control. Note Stra8 is observed only in control sample C2, 2D PMSG sample 2D2 and 7D PMSG sample 7D2 at very low levels compared to testicular sample. Meiotic marker Scp3 and Dmc1 are upregulated in PMSG treated samples. Each sample was obtained by pooling ovaries from two animals.

may reflect a quick transition of pre-meiotic germ cells, once committed by inducing Stra8 expression, into oocytes during young adulthood. On the other hand, meiotic markers Scp3 and Dmc1 were detected in all the samples studied, albeit at very low levels in control samples. This suggests meiosis occurrence at extremely low level in normal adult ovary, while it is upregulated during PMSG treatment. To further confirm this, Q-PCR analysis of Scp3 was performed.

\section{Q-PCR analysis of various transcripts}

The Q-PCR data obtained by analysis of control and PMSG treated ovaries is presented (Figure 10). As expected, a significant increase in Fshr mRNA expression was noted on 2D after PMSG treatment compared to control sample and showed slight reduction by 7D. PMSG treatment also led to increased stem cell activity as evident by increase in expression of stem cell and primordial germ cell markers including Oct-4A, Nanog, total Oct-4, Fragilis and Stella on D2 after PMSG and were further increased or sustained by D7. As mentioned earlier, we have previously reported that the pluripotent VSELs have nuclear OCT-4 (specific transcript is Oct-4A) and once they initiate differentiation, OCT-4 shifts to cytoplasm in OGSCs [32]. Results of the present study indicate that the increase in total Oct- 4 post PMSG treatment was more than the increase in Oct-4A (Figure 10), suggesting that OGSCs are also proliferating postPMSG treatment. Also increase in expression was observed in germ cell marker (Mvh) and interestingly significant increase in Nobox was maximally observed on 7D. HoxA10 was decreased on 2D post treatment probably because of maturation of pre-existing primordial and primary follicles. Interestingly, the HoxA10 levels increased on 7D and reached levels comparable to control suggesting formation of new primordial follicles post PMSG treatment. RT-PCR and Q-PCR analysis for the meiotic marker Scp3 also showed a significant increase 7D after PMSG treatment suggesting increase in meiosis post treatment.

\section{Discussion}

Present study demonstrates that pluripotent stem cells VSELs and progenitors OGSCs reported earlier by our group in adult mice, rabbit, sheep, monkey and human ovary $[32,39]$ are possibly regulated by FSH and are responsible for postnatal oogenesis and follicular assembly during adult reproductive life. Normal adult mice ovaries were studied during different stages of estrus cycle and after 2 and 7 days of PMSG treatment by histology, immunolocalization (FSHR, PCNA, OCT-4, SCP3 and MVH), and RT$\mathrm{PCR} / \mathrm{Q}-\mathrm{PCR}$ for various gene transcripts including pluripotent (Oct-4A, Nanog); early germ cell (total Oct-4, Stella, Fragilis, Mvh), oocyte-specific (Nobox \& HoxA10); premeiosis (Stra8) and meiosis (Scp3, Dmc1) specific markers. The process of ovarian stem cell differentiation and meiosis giving rise to new oocytes, which get enclosed by the granulosa cells to assemble as PFs in the OSE appears to be a normal feature of adult ovary (Figure 1,2). The granulosa cells arise by epithelial-mesenchymal transition of OSE as suggested earlier by us based on in vitro evidence [32]. Present study provides in vivo evidence in favor of our earlier observations that OSE cells may be involved in the formation of granulosa cells (Figure 6B,C, E \& F). PMSG treatment further augments the process of postnatal oogenesis and PF assembly resulting in increased PFs by D7 (Figure $3,4,5,6$ ).

PMSG is known to exert its actions on mammalian ovary through FSH-FSHR interaction. In the present study, besides granulosa cells of bigger follicles, FSHR was detected in both OSE and oocytes of PF in agreement with earlier reports $[15-17,19,27,28]$ and an up-regulation was observed after PMSG treatment at both protein by immunohistochemistry (Figure 7) and transcript (Figure 10) level. Presence of FSHR in locations like oocytes and OSE 


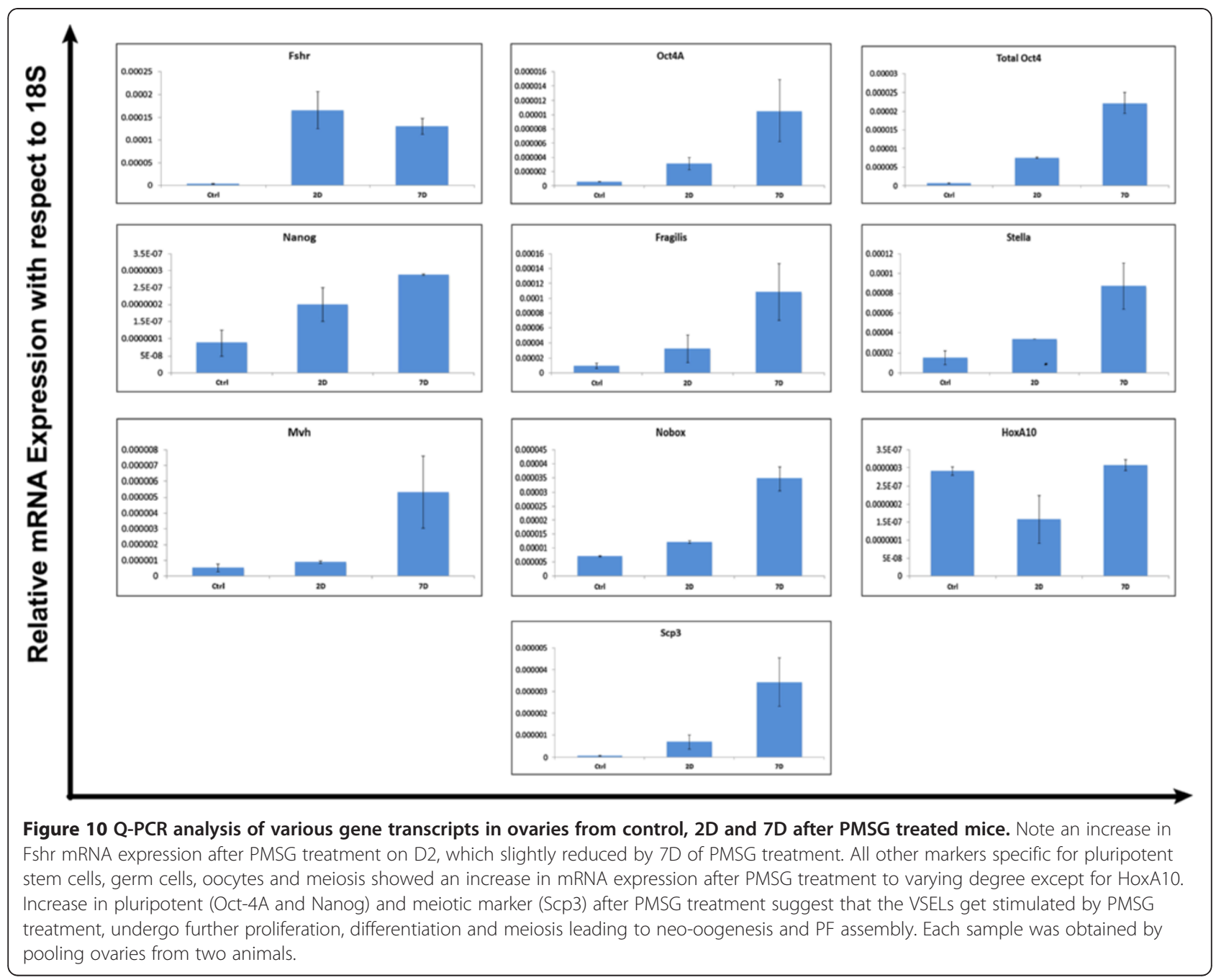

suggests that the various diverse functions of FSH are probably not exerted only through the classical FSHR present on the granulosa cells of growing follicles. Sairam's group has earlier reported that FSH may exert diverse actions through alternatively spliced FSHR isoforms based on their studies from sheep and mice ovaries [62-64].

In the current study, upregulation of FSHR after PMSG treatment correlated well to the proliferation observed in OSE. OSE proliferation and multilayer appearance which were normally observed in control ovaries at few focal areas were increased after PMSG treatment (Figure 3 \& 4). Ovarian sections on 2D of PMSG treatment showed the presence hyperplastic epithelial cells and small protuberances bulging from the ovarian surface (Figure 3) which subside by 7D (Figure 4, 5, 6). PF cohorts normally observed with hyper-proliferative OSE regions in control ovaries, increased significantly after 7D of PMSG treatment in the ovarian cortex (Figure $4 \& 5$ ). This correlated well with increased mRNA expression for HoxA10- a primordial follicular oocyte marker [58] and Nobox that is expressed abundantly in primordial and primary follicular oocytes [58] post PMSG treatment. Occurrence of meiosis was supported by expression of pre-meiotic (Stra8) and meiotic (Scp3 and Dmc 1) markers. All the three markers were detected in control as well as all PMSG treated ovarian samples. A distinct up regulation of Scp3 was noted after PMSG treatment, both at the protein (Figure $8 \mathrm{H}$ $\mathrm{J})$ and mRNA transcript level (Figure 9 \&10). As reported earlier [65], SCP3 staining was observed throughout the nuclei suggesting that the oocytes are in prophase I of meiosis and was gradually lost in more developed oocytes. The PF at birth are generally arrested in diplotene stage of prophase 1 of meiosis. SCP3 expression is restricted to earlier stages i.e. zygotene and pachytene stage. Thus expression of Scp3 and pre-meiotic marker Stra8 in adult ovary are considered direct evidence in support of postnatal oogenesis and have been reported earlier by other groups also $[36,66]$.

It is intriguing to point out that OSE which expresses FSHR also lodges VSELs as observed in rabbit, sheep, 
monkey, human [32] and also mouse ovaries [39]. The VSELs with nuclear OCT-4 differentiate into 'progenitors' ovarian germ stem cells (OGSCs) with cytoplasmic OCT-4 and undergo spontaneous differentiation into oocyte-like structures in vitro [32,37]. Possibly, in the present study, the pluripotent VSELs were activated by PMSG treatment (increased expression of Oct-4A, Nanog Figure 8 \& 10), undergo proliferation (increased PCNA staining and Oct-4A expression, Figure 8) and differentiation (increased expression of stella, fragilis, total Oct-4, Vasa and MVH Figure 8 \& 10) resulting in meiosis (Stra-8, Scp3 and Dmc1 Figure 8, 9, 10) and formation of oocyte nests with prominent intercellular cytoplasmic bridges that assemble to form $\mathrm{PF}$ in the OSE (Figure $2 \& 6$ ). These nests later shift to the cortex and are visualized as small cohorts on 7D after PMSG treatment. This data demonstrates the mechanism of oogenesis occurring in situ in adult ovary for the first time in OSE similar to well-studied spermatogenesis in the testicular seminiferous tubules where the VSELs are lodged at the basement membrane $[67,68]$. The process is regulated by FSH and is in contradiction to the existing paradigm that initial PF growth is gonadotropin independent $[69,70]$. The results of the present study support the model for postnatal oogenesis proposed by us earlier [39].

Messinis et al. [70] have reviewed a huge body of literature and summarized the current understanding of the role played by FSH during folliculogenesis. According to existing understanding, the 'intercycle peak' of FSH is crucial and responsible for 'cyclic recruitment' of follicles. Ovary experiences waves of folliculogenesis and a cohort of follicles start growing in each cycle, however, only one becomes dominant and others undergo atresia [69]. On treating with gonadotropins, FSH window gets widened and multiple follicles get selected and start to grow. Whether more follicles get recruited due to the treatment or FSH prevents atresia in the already recruited cohort of PF is still controversial. Results of the present study add another dimension to this by demonstrating that FSH also exerts action on the OSE and induces neo-oogenesis and PF assembly from the stem cells residing in the OSE.

The prevailing notion of extrusion of atretic oocytes from the ovary surface [71-73] or that the PF may get pushed to the ovarian surface because of the growing follicles in response to the PMSG treatment (and thus increased number of PF are visualized after treatment in the present study) may not be valid since this reasoning cannot account for distinct increased pattern of pluripotent and meiotic markers in the developing follicles (Figure 7, 8, 9) observed in the present study. Also the earlier published reports of BrdU incorporation in OSE $[34,36]$ may not be due to mtDNA synthesis - rather it may be due to stem cell activity that gets augmented by PMSG.

The extensive germ cell nest formation, initiation of meiosis, PF assembly etc. are well documented and studied during fetal ovarian development in the existing literature [60]. It is interesting to point out that the stage of fetal development when PF assembly occurs is actually associated with several folds higher levels of FSH in females [2-6,74]. Thus FSH is directly related to PF assembly and regular intercycle peak of FSH may be stimulating the VSELs to result in differentiation and PF assembly. Lei et al. [74] reported that the high levels of circulatory FSH in perinatal period and increased FSHR mRNA in mouse ovaries facilitate germline nest breakdown and PF assembly.

\section{Conclusions}

We propose that PMSG treatment through induction of FSH-FSHR action possibly stimulates the pluripotent VSELs residing in the OSE leading to proliferation and differentiation of OGSCs to oocytes and primordial follicle assembly. These results are in contradiction to the existing paradigm that ovaries have fixed number of follicles in adulthood and that early PF growth is independent of FSH.

The results of the present study are in direct agreement with postnatal oogenesis proposed by Tilly's group in 2004 [36]. We propose that intercycle FSH peak is probably associated with cyclic recruitment of VSELs in the OSE throughout reproductive life and results in neo-oogenesis and PF assembly. Several fold elevated FSH levels in female fetus during peri-natal period [2-6] are possibly responsible for increased PF assembly well documented during fetal development. Moreover, since VSELs exist in various body organs, it would be interesting to study whether only ovarian VSELs are selectively stimulated by FSH or even VSELs in testis $[67,68]$ or bone marrow [75] etc. are also regulated by FSH. It is indeed intriguing that despite exploiting the ovaries for so many years as a source of eggs, present study has provided newer information towards the mechanism of action of FSH on the ovaries. Elevated FSHR3 (an isoform of FSHR) in OSE has been implicated in ovarian cancers [25]. It is highly likely that the VSELs residing in the OSE may also be implicated in the ovarian cancers as has been proposed earlier [76,77].

\footnotetext{
Abbreviations

2D PMSG: 2 Days post PMSG treatment; 7D PMSG: 7 Days post PMSG treatment; DE: Diestrus; FSH: Follicle stimulating hormone; FSHR: Follicle stimulating hormone receptor; OGSCs: Ovarian germ stem cells; OSE: Ovarian surface epithelium; PF: Primordial follicle; PMSG: Pregnant mare serum gonadotropin; Q-PCR: Quantitative polymerase chain reaction; RTPCR: Reverse transcription polymerase chain reaction; VSELs: Very small embryonic like stem cell.
}

\section{Competing interests}

Authors declare no competing interests. 


\section{Authors' contributions}

DB was responsible for conceptualizing the study, data interpretation and manuscript preparation. KS was responsible for RT PCR and Q PCR analysis, data compilation and manuscript preparation. PG was responsible for immunolocalization studies and data compilation. HM was responsible for histology studies. All read and approve the final manuscript.

\section{Acknowledgements}

We thank Dr Smita Mahale, Structural Biology Department, NIRRH for FSHR antibody. We also acknowledge financial support from Department of Science and Technology, Government of India, New Delhi for KS and Department of Biotechnology, Government of India, New Delhi for PG and HM. The work was carried out using NIRRH core support from ICMR.

Received: 30 August 2012 Accepted: 13 October 2012

Published: 7 November 2012

\section{References}

1. Garor R, Abir R, Erman A, Felz C, Nitke S, Fisch B: Effects of basic fibroblast growth factor on in vitro development of human ovarian primordial follicles. Fertil Steril 2009, 91(5 Suppl):1967-1975.

2. Halpin DMG, Jones A, Fink G, Charlton HM: Postnatal ovarian follicle development in hypogonadal (hpg) and normal mice and associated changes in the hypothalamic pituitary axis. J Reprod Fertil 1986, 77(1):287-296

3. Uilenbroek JTHJ, Arendsen DWE, Welschen R: Studies on the signifi- cance of the high levels of follicle-stimulating hormone for follicular development in immature rats. Ann Biol Anim Biochem Biophys 1976, 16:297-305.

4. Vomachka AJ, Greenwald GS: The development of gonadotropin and steroid hormone patterns in male and female from birth to puberty. Endocrinology 1979, 105(4):960-966.

5. Roy SK, Hughes J: Ontogeny of granulosa cells in the ovary: lineage specific expression of transforming growth factor beta 2 and transforming growth factor 1. Biol Reprod 1994, 51(5):821-830.

6. Debieve F, Beerlandt S, Hubinont C, Thomas K: Gonadotropins, prolactin, inhibin $A$, inhibin $B$, and activin $A$ in human fetal serum from midpregnancy and term pregnancy. J Clin Endocrinol Metab 2000, 85(1):270-274.

7. Broekmans FJ, Soules MR, Fauser BC: Ovarian aging: mechanisms and clinical consequences. Endocr Rev 2009, 30(5):465-493.

8. High FSH, advanced maternal Age, poor egg quality - Can we turn back the reproductive clock? [http://www.acupuncturepittsburgh.com/pdf/Fertility.pdf].

9. Bose CK: Follicle stimulating hormone receptor in ovarian surface epithelium and epithelial ovarian cancer. Oncol Res 2008, 17(5):231-238.

10. Wang J, Lin L, Parkash V, Schwartz PE, Lauchlan SC, Zheng W: Quantitative analysis of follicle-stimulating hormone receptor in ovarian epithelial tumors: a novel approach to explain the field effect of ovarian cancer development in secondary mullerian systems. Int J Cancer 2003, 103(3):328-334.

11. Wright CS, Hovatta O, Margara R, Trew G, Winston RM, Franks S, Hardy K: Effects of follicle-stimulating hormone and serum substitution on the in-vitro growth of human ovarian follicles. Hum Reprod 1999, 14(6):1555-1562.

12. Roy SK, Albee $L$ : Requirement for follicle-stimulating hormone action in the formation of primordial follicles during perinatal ovarian development in the hamster. Endocrinology 2000, 141(12):4449-4456.

13. Demeestere I, Streiff AK, Suzuki J, Al-Khabouri S, Mahrous E, Tan SL, Clarke $\mathrm{HJ}$ : Follicle- stimulating hormone accelerates mouse oocyte development in vivo. Biol Reprod 2012, 87(1):3.

14. Rao AJ, Ramachandra SG, Ramesh V, Couture L, Abdennebi L, Salesse R, Remy Jj: Induction of infertility in adult male bonnet monkeys by immunization with phage-expressed peptides of the extracellular domain of FSH receptor. Reprod Biomed Online 2004, 8(4):385-391.

15. Zheng W, Magid MS, Kramer EE, Chen YT: Follicle-stimulating hormone receptor is expressed in human ovarian surface epithelium and fallopian tube. Am J Pathol 1996, 148(1):47-53.

16. Ji Q, Liu PI, Chen PK, Aoyama C: Follicle stimulating hormone-induced growth promotion and gene expression profiles on ovarian surface epithelial cells. Int J Cancer 2004, 112(5):803-814.
17. Parrott JA, Doraiswamy V, Kim G, Mosher R, Skinner MK: Expression and actions of both the follicle stimulating hormone receptor and the luteinizing hormone receptor in normal ovarian surface epithelium and ovarian cancer. Mol Cell Endocrinol 2001, 172(1-2):213-222.

18. Minegishi T, Kameda T, Hirakawa T, Abe K, Tano M, Ibuki Y: Expression of gonadotropin and activin receptor messenger ribonucleic acid in human ovarian epithelial neoplasms. Clin Cancer Res 2000, 6(7):2764-2770.

19. Syed V, Ulinski G, Mok SC, Yiu GK, Ho SM: Expression of gonadotropin receptor and growth responses to key reproductive hormones in normal and malignant human ovarian surface epithelial cells. Cancer Res 2001, 61(18):6768-6776

20. Parrott JA, Nilsson E, Mosher R, Magrane G, Albertson D, Pinkel D, Gray JW, Skinner MK: Stromal-epithelial interactions in the progression of ovarian cancer: influence and source of tumor stromal cells. Mol Cell Endocrinol 2001, 175(1-2):29-39.

21. Choi KC, Kang SK, Tai CJ, Auersperg N, Leung PC: Follicle-stimulating hormone activates mitogen-activated protein kinase in preneoplastic and neoplastic ovarian surface epithelial cells. J Clin Endocrinol Metab 2002, 87(5):2245-2253.

22. Choi JH, Choi KC, Auersperg N, Leung PC: Overexpression of folliclestimulating hormone receptor activates oncogenic pathways in preneoplastic ovarian surface epithelial cells. J Clin Endocrinol Metab 2004, 89(11):5508-5516.

23. Choi JH, Choi KC, Auersperg N, Leung PC: Differential regulation of two forms of gonadotropin-releasing hormone messenger ribonucleic acid by gonadotropins in human immortalized ovarian surface epithelium and ovarian cancer cells. Endocr Relat Cancer 2006, 13(2):641-651.

24. Abd-Elaziz M, Moriya T, Akahira J, Nakamura Y, Suzuki T, Sasano H: Immunolocalization of nuclear transcription factors, DAX-1 and Ad4BP/SF-1, in human common epithelial ovarian tumors: correlations with StAR and steroidogenic enzymes in epithelial ovarian carcinoma. Int J Gynecol Pathol 2005, 24(2):153-163.

25. Li Y, Ganta S, Cheng C, Craig R, Ganta RR, Freeman LC: FSH stimulates ovarian cancer cell growth by action on growth factor variant receptor. Mol Cell Endocrinol 2007, 267(1-2):26-37.

26. Choi JH, Wong AS, Huang HF, Leung PC: Gonadotropins and ovarian cancer. Endocr Rev 2007, 28(4):440-461.

27. Patsoula E, Loutradis D, Drakakis P, Kallianidis K, Bletsa R, Michalas S: Expression of mRNA for the LH and FSH receptors in mouse oocytes and preimplantation embryos. Reproduction 2001, 121(3):455-461.

28. Méduri G, Charnaux N, Driancourt MA, Combettes L, Granet P, Vannier B, Loosfelt $\mathrm{H}$, Milgrom E: Follicle-stimulating hormone receptors in oocytes? J Clin Endocrinol Metab 2002, 87(5):2266-2276.

29. Burdette JE, Kurley SJ, Kilen SM, Mayo KE, Woodruff TK: Gonadotropininduced superovulation drives ovarian surface epithelia proliferation in CD1 mice. Endocrinology 2006, 147(5):2338-2345.

30. Davies BR, Finnigan DS, Smith SK, Ponder BA: Administration of gonadotropins stimulates proliferation of normal mouse ovarian surface epithelium. Gynecol Endocrinol 1999, 13(2):75-81.

31. Stewart SL, Querec TD, Gruver BN, O'Hare B, Babb JS, Patriotis C: Gonadotropin and steroid hormones stimulate proliferation of the rat ovarian surface epithelium. J Cell Physiol 2004, 198(1):119-124.

32. Parte S, Bhartiya D, Telang J, Daithankar V, Salvi V, Zaveri K, Hinduja I: Detection, characterization, and spontaneous differentiation in vitro of very small embryonic-like putative stem cells in adult mammalian ovary. Stem Cells Dev 2011, 20(8):1451-1464.

33. Pacchiarotti J, Maki C, Ramos T, Marh J, Howerton K, Wong J, Pham J, Anorve S, Chow YC, Izadyar F: Differentiation potential of germ line stem cells derived from the postnatal mouse ovary. Differentiation 2010, 79(3):159-170

34. Zou K, Yuan Z, Yang Z, Luo H, Sun K, Zhou L, Xiang J, Shi L, Yu Q, Zhang Y, Hou R, Wu J: Production of offspring from a germline stem cell line derived from neonatal ovaries. Nat Cell Biol 2009, 11(5):631-636.

35. Zhang D, Fouad H, Zoma WD, Salama SA, Wentz MJ, Al-Hendy A: Expression of stem and germ cell markers within nonfollicle structures in adult mouse ovary. Reprod Sci 2008, 15(2):139-146.

36. Johnson J, Canning J, Kaneko T, Pru JK, Tilly JL: Germline stem cells and follicular renewal in the postnatal mammalian ovary. Nature 2004 428(6979):145-150

37. Virant-Klun I, Zech N, Rozman P, Vogler A, Cvjeticanin B, Klemenc P, Malicev E, Meden-Vrtovec H: Putative stem cells with an embryonic 
character isolated from the ovarian surface epithelium of women with no naturally present follicles and oocytes. Differentiation 2008, 76(8):843-856.

38. Bukovsky A, Caudle MR, Svetlikova M, Upadhyaya NB: Origin of germ cells and formation of new primary follicles in adult human ovaries. Reprod Biol Endocrinol 2004, 2:20

39. Bhartiya D, Sriraman K, Parte S: Stem cell interaction with somatic niche may hold the key to fertility restoration in cancer patients. Obstet Gynecol Int 2012, 2012:921082. PMID: 22548074.

40. Virant-Klun I, Stimpfel M, Skutella T: Stem cells in adult human ovaries: from female fertility to ovarian cancer. Curr Pharm Des 2012, 18:283-292.

41. Woods DC, White YA, Tilly JL: Purification of oogonial stem cells from adult mouse and human ovaries: An assessment of the literature and a view toward the future. Reprod Sci 2012, [Epub ahead of print].

42. Bukovsky A: Ovarian stem cell niche and follicular renewal in mammals. Anat Rec (Hoboken) 2011, 294:1284-1306.

43. Zhang H, Zheng W, Shen Y, Adhikari D, Ueno H, Liu K: Experimental evidence showing that no mitotically active female germline progenitors exist in postnatal mouse ovaries. Proc Natl Acad Sci 2012, 109:12580-12585.

44. Byskov AG, Hoyer PE, Andersen CY, Kristensen SG, Jespersen A, Mollgard K: No evidence for the presence of oogonia in the human ovary after their final clearance during the first two years of life. Hum Reprod 2011, 26:2129-2139.

45. White YA, Woods DC, Takai Y, Ishihara O, Seki H, Tilly JL: Oocyte formation by mitotically active germ cells purified from ovaries of reproductive-age women. Nat Med 2012, 18(3):413-21.

46. Bhartiya D: The continued presence of stem cells and oogonia in the adult mammalian ovary. Hum Reprod 2012, 27(3):938.

47. Telfer EE, Albertini DF: The quest for human ovarian stem cells. Nat Med 2012, 18(3):353-4

48. Gamwell LF, Collins O, Vanderhyden BC: The mouse ovarian surface epithelium contains a population of LY6A (SCA-1) expressing progenitor cells that are regulated by ovulation-associated factors. Biol Reprod 2012 Epub ahead of print.

49. Ghosalkar JD, Dharma SJ, Nandedkar TD, Mahale SD: Identification of the region 285-309 of follicle stimulating hormone receptor as a bioneutralizing epitope. J Reprod Immunol 2007, 74(1-2):24-33.

50. Tan OL, Fleming JS: Proliferating cell nuclear antigen immunoreactivity in the ovarian surface epithelium of mice of varying ages and total lifetime ovulation number following ovulation. Biol Reprod 2004, 71(5):1501-1507.

51. Toyooka Y, Tsunekawa N, Takahashi Y, Matsui Y, Satoh M, Noce T: Expression and intracellular localization of mouse Vasa-homologue protein during germ cell development. Mech Dev 2000, 93(1-2):139-149.

52. Raz $\mathrm{E}$ : The function and regulation of vasa-like genes in germ-cell development. Genome Biol 2000, 1(3):1-1017. reviews1017.6.

53. Lee J, Kim HK, Rho JY, Han YM, Kim J: The human OCT-4 isoforms differ in their ability to confer self-renewal. J Biol Chem 2006, 281(44):33554-33565.

54. Zuba-Surma EK, Kucia M, Ratajczak J, Ratajczak MZ: "Small stem cells" in adult tissues: very small embryonic-like stem cells stand up! Cytometry $A$ 2009, 75(1):4-13

55. Yamaguchi S, Kimura H, Tada M, Nakatsuji N, Tada T: Nanog expression in mouse germ cell development. Gene Expr Patterns 2005, 5(5):639-646.

56. Payer B, Saitou M, Barton SC, Thresher R, Dixon JP, Zahn D, Colledge WH, Carlton MB, Nakano T, Surani MA: Stella is a maternal effect gene required for normal early development in mice. Curr Biol 2003, 13(23):2110-2117.

57. Lange UC, Saitou M, Western PS, Barton SC, Surani MA: The fragilis interferon-inducible gene family of transmembrane proteins is associated with germ cell specification in mice. BMC Dev Biol 2003, 3:1

58. Huntriss J, Hinkins M, Picton HM: cDNA cloning and expression of the human NOBOX gene in oocytes and ovarian follicles. Mol Hum Reprod 2006, 12(5):283-289

59. Menke DB, Koubova J, Page DC: Sexual differentiation of germ cells in XX mouse gonads occurs in an anterior-to-posterior wave. Dev Biol 2003, 262(2):303-312.

60. Pepling ME: Follicular assembly: mechanisms of action. Reproduction 2012, 143(2):139-149.

61. Niikura Y, Niikura T, Tilly JL: Aged mouse ovaries possess rare premeiotic germ cells that can generate oocytes following transplantation into a young host environment. Aging (Albany NY) 2009, 1(12):971-978.
62. Babu PS, Jiang L, Sairam AM, Touyz RM, Sairam MR: Structural features and expression of an alternatively spliced growth factor type I receptor for follitropin signaling in the developing ovary. Mol Cell Biol Res Commun 1999, 2(1):21-27

63. Babu PS, Danilovich N, Sairam MR: Hormone-induced receptor gene splicing: enhanced expression of the growth factor type I folliclestimulating hormone receptor motif in the developing mouse ovary as a new paradigm in growth regulation. Endocrinology 2001 142(1):381-389.

64. Sairam MR, Babu PS: The tale of folitropin receptor diversity: A recipe for fine tuning gonadal responses? Mol Cell Endocrinol 2007, 260-262:163-171.

65. Prieto I, Tease C, Pezzi N, Buesa JM, Ortega S, Kremer L, Martínez A, Martínez-A C, Hultén MA, Barbero JL: Cohesin component dynamics during meiotic prophase I in mammalian oocytes. Chromosome Res 2004, 12(3):197-213

66. Bukovsky A, Caudle MR, Gupta SK, Svetlikova M, Selleck-White R, Ayala AM, Dominguez R: Mammalian neo-oogenesis and expression of meiosisspecific protein SCP3 in adult human and monkey ovaries. Cell Cycle 2008, 7(5):683-686.

67. Bhartiya D, Kasiviswanathan S, Unni SK, Pethe P, Dhabalia JV, Patwardhan S, Tongaonkar HB: Newer insights into premeiotic development of germ cells in adult human testis using Oct-4 as a stem cell marker. J Histochem Cytochem 2010, 58(12):1093-1106.

68. Bhartiya D, Kasiviswananthan S, Shaikh A: Cellular origin of testis-derived pluripotent stem cells: a case for very small embryonic-like stem cells. Stem Cells Dev 2012, 21(5):670-674.

69. Gougeon A: Dynamics of follicular growth in the human: a model from preliminary results. Hum Reprod 1986, 1(2):81-87.

70. Messinis IE, Messini Cl, Dafopoulos K: The role of gonadotropins in the follicular phase. Ann N Y Acad Sci 2010, 1205:5-11.

71. Gosden R, Telfer E, Faddy M: Germ line stem cells and adult ovarian function. In Stem Cells in Human Reproduction. 2nd edition. Edited by Simón C, Pellicer A. Informa Healthcare; 2009:57-68. http:// informahealthcare.com/doi/abs/10.3109/9781841847290.006

72. Kerr JB, Duckett R, Myers M, Britt KL, Mladenovska T, Findlay JK: Quantification of healthy follicles in the neonatal and adult mouse ovary: evidence for maintenance of primordial follicle supply. Reproduction 2006, 132(1):95-109.

73. Motta PM, Makabe S, Nottola SA: The ultrastructure of human reproduction. I. The natural history of the female germ cell: origin, migration and differentiation inside the developing ovary. Hum Reprod Update 1997, 3(3):281-295.

74. Lei L, Jin S, Mayo KE, Woodruff TK: The interactions between the stimulatory effect of follicle-stimulating hormone and the inhibitory effect of estrogen on mouse primordial folliculogenesis. Biol Reprod 2010, 82(1):13-22.

75. Bhartiya D: Pluripotent very small embryonic-like stem cells get discarded during cord blood and bone marrow processing. Stem Cells Dev 2012, 21(14):2563-4.

76. Ratajczak MZ, Shin DM, Kucia M: Very small embryonic/epiblast-like stem cells: a missing link to support the germ line hypothesis of cancer development? Am J Pathol 2009, 174(6):1985-1992.

77. Ratajczak MZ, Shin DM, Liu R, Marlicz W, Tarnowski M, Ratajczak J, Kucia M: Epiblast/germ line hypothesis of cancer development revisited: lesson from the presence of Oct-4(1) cells in adult tissues. Stem Cell Rev 2010, 6(2):307-316.

\section{doi:10.1186/1757-2215-5-32}

Cite this article as: Bhartiya et al:: Gonadotropin treatment augments postnatal oogenesis and primordial follicle assembly in adult mouse ovaries? Journal of Ovarian Research 2012 5:32 